\title{
PENGARUH POLA KOMUNIKASI ORANG TUA TUNGGAL DAN KELOMPOK TEMAN SEBAYA TERHADAP PRESTASI BELAJAR SISWA KELAS XI PEMASARAN SMK NEGERI 7 MEDAN TAHUN AJARAN 2019/2020
}

\author{
${ }^{1)}$ Ainul Mardhiyah ${ }^{2)}$ Tianisa Hutasuhut \\ *korespondensi : tianisa79@gmail.com
}

\author{
${ }^{1)}$ Program Studi Pendidikan Ekonomi, Fakultas Ekonomi, Universitas Negeri Medan \\ ${ }^{2)}$ Program Studi Pendidikan Ekonomi, Fakultas Ekonomi, Universitas Negeri Medan
}

ABSTRACT

\begin{abstract}
The problem in this research is Single Parent Communication Patterns And peer group which is not good resulting in low student achievement. This study aims to determine the effect of Single Parent Communication Patterns And peer group Of Student Achievement in Class XI Marketing at SMK Negeri 7 Medan Academic Year 2019/2020. The population in this study were all class students XI Marketing at SMK Negeri 7 Medan Academic Year 2019/2020 consists of two classes: XI Marketing classes 1 and XI Marketing classes 2 with the number of 33 students. The samples in this study using the Theory Arikunto with sample techniques is Total Sampling. Data collection techniques used were observation, questionnaires and documentation. The study states that: (1) There is a negative and significant influence between Single Parent Communication Patterns Of Student Achievement in Class XI Marketing at SMK Negeri 7 Medan Academic Year 2019/2020). (2) There is a positive and significant influence between peer group Of Student Achievement in Class XI Marketing at SMK Negeri 7 Medan Academic Year 2019/2020). (3) There is a significant influence between Single Parent Communication Patterns and peer group Of Student Achievement in Class XI Marketing at SMK Negeri 7 Medan Academic Year 2019/2020. Thus it can be concluded that there is the effect of Single Parent Communication Patterns And peer group Of Student Achievement in Class XI Marketing at SMK Negeri 7 Medan Academic Year 2019/2020.
\end{abstract}

\section{Keywords: Single Parent Communication Patterns, Peer Group and Student Achievement}

\section{ABSTRAK}

Permasalahan dalam penelitian ini adalah pola komunikasi orang tua tunggal dan kelompok teman sebaya yang tidak baik mengakibatkan prestasi belajar siswa rendah. Penelitian ini bertujuan untuk mengetahui Pengaruh Pola Komunikasi Orang Tua Tunggal Dan Kelompok Teman Sebaya Terhadap Prestasi Belajar Siswa Kelas XI Pemasaran SMK Negeri 7 Medan Tahun Ajaran 2019/2020. Populasi dalam penelitian ini adalah seluruh Siswa Kelas XI Pemasaran SMK Negeri 7 Medan Tahun Ajaran 2019/2020 yang terdiri dari 2 kelas yaitu kelas XI Pemasaran 1 dan XI Pemasaran 2 dengan jumlah 33 siswa. Pengambilan sampel dalam penelitian ini menggunakan Teori Arikunto dengan teknik sampel yaitu Total Sampling. Teknik pengumpulan data yang digunakan adalah observasi, angket dan dokumentasi. Teknik analisis data yang digunakan dalam penelitian ini adalah Regresi Linear berganda. Hasil penelitian menyatakan bahwa : (1) Terdapat pengaruh yang negatif dan signifikan antara Pola Komunikasi Orang Tua Tunggal terhadap Prestasi Belajar Siswa Kelas XI Pemasaran SMK Negeri 7 Medan Tahun Ajaran 2019/ 2020 (2) Terdapat pengaruh yang positif dan signifikan antara Kelompok Teman Sebaya Terhadap Prestasi Belajar Siswa Kelas XI Pemasaran SMK Negeri 7 Medan Tahun Ajaran 2019/ 2020 (3) Terdapat pengaruh signifikan antara Pola Komunikasi Orang Tua Tunggal dan Kelompok Teman Sebaya Terhadap Prestasi Belajar Siswa Kelas XI Pemasaran SMK Negeri 7 Medan Tahun Ajaran 2019/ 2020. Dengan demikian dapat disimpulkan bahwa terdapat Pengaruh Pola Komunikasi Orang Tua Tunggal Dan Kelompok Teman Sebaya Terhadap Prestasi Belajar Siswa Kelas XI Pemasaran SMK Negeri 7 Medan Tahun Ajaran 2019/ 2020.

Kata Kunci: Pola Komunikasi Orang Tua Tunggal, Kelompok Teman Sebaya, Prestasi Belajar. 


\section{PENDAHULUAN}

Perkembangan zaman yang semakin maju menuntut adanya peningkatan kualitas sumber daya manusia. Salah satu cara untuk meningkatkan sumber daya manusia adalah melalui pendidikan. Melalui pendidikan individu dapat meningkatkan pengetahuan dan keterampilan sehingga menjadi individu yang memiliki kualitas yang maksimal untuk menguasai kemajuan ilmu pengetahuan dan teknologi yang berkembang di masyarakat serta mampu menjadi pribadi yang tangguh dan ikut serta membangun negaranya. Disamping itu, melalui pendidikan manusia mendapatkan keterampilan, nilai dan sikap sehingga dapat berpikir lebih sistematis, rasional dan kritis terhadap permasalahan yang dihadapinya.

Menurut UU No. 20 Tahun 2003 tentang Sistem Pendidikan Nasional menyatakan bahwa: pendidikan nasional berfungsi mengembangkan kemampuan dan membentuk watak serta peradaban bangsa yang bermartabat dalam rangka mencerdaskan kehidupan bangsa, bertujuan untuk mengembangkan potensi peserta didik agar menjadi manusia yang beriman dan bertaqwa kepada Tuhan Yang Maha Esa, berakhlak mulia, sehat, berilmu, cakap, kreatif, mandiri dan menjadi warga negara yang demokratis dan bertanggung jawab.

Melalui pendidikan nasional inilah diharapkan tercipta manusia-manusia yang berkualitas dan berkompeten. Kualitas pendidikan siswa dapat dilihat melalui prestasi berlajarnya. Prestasi belajar merupakan hasil dari pengukuran dan penilaian usaha belajar. Bukti keberhasilan dari seseorang setelah memperoleh pengalaman belajar atau mempelajari sesuatu merupakan prestasi belajar yang dicapai oleh peserta didik dalam waktu tertentu.

Prestasi belajar yang dicapai oleh siswa mencerminkan tingkat pemahaman siswa terhadap mata pelajaran yang dipelajarinya. Suatu proses Kegiatan Belajar Mengajar (KBM) yang sudah berlangsung dapat dikatakan berhasil apabila siswa memperoleh prestasi belajar yang baik atau dengan kata lain prestasi belajar siswa sama dengan atau lebih besar dari Kriteria Ketuntasan Minimal (KKM) yang ditetapkan.

Salah satu faktor yang mempengaruhi prestasi belajar siswa tersebut rendah dipengaruhi oleh pola komunikasi orang tua. Karena dalam lingkungan keluarga pun komunikasi juga merupakan suatu hal yang sangat penting, komunikasi sebagai alat atau sebagai media penjembatan dalam hubungan antar sesama anggota keluarga. Buruknya kualitas komunikasi dalam keluarga akan berdampak buruk bagi keutuhan dan keharmonisan dalam keluarga itu sendiri.

Orang tua biasanya mempunyai berbagai cara dan strategi untuk berkomunikasi dan mendidik ketika anaknya masuk ke dunia remaja agar menjadi sesuai dengan apa yang diinginkan, karena keluarga merupakan salah satu tempat pendidikan informal terpenting untuk pendidikan anak, maka pola komunikasi apapun akan mempengaruhi proses pertumbuhan dan perkembangan anak dalam 
segi apapun. Menurut Yusuf (2004:34), Bagi seorang anak, keluarga merupakan tempat pertama dan utama bagi pertumbuhan dan perkembangannya, fungsi utama keluarga adalah sebagai wahana untuk berkomunikasi, mendidik, mengasuh, dan mensosialisasikan anak, mengembangkan kemampuan seluruh anggotanya agar dapat menjalankan fungsinya di masyarakat dengan baik.

Kenyataannya tidak semua anak memiliki orang tua yang lengkap, lebih banyak anak hidup tanpa keberadaan ayah/ibu disampingnya. Orang tua tunggal adalah fenomena yang makin dianggap biasa dalam masyarakat modern. Masalah besar yang orang tua tunggal hadapi yaitu masalah emosional, masalah hukum (hak asuh dan lain-lain), menjalin hubungan dengan mantan pasangan, masalah keuangan, masalah lingkungan dan menghadapi anak. Orang tua tunggal akibat dari perceraian dapat membangun pola komunikasi yang baik dengan anaknya, karena bagi anak yang tiba-tiba mendapati orang tuanya tidak lengkap lagi karena orang tuanya bercerai dapat memberi dampak psikologis yang kurang baik. (http://www.indonesia.com/intisari/2001/Jun/w arna orangtuatunggal.htm).

Apabila tidak adanya komunikasi yang bagus antara orang tua tunggal dengan anaknya maka para orang tua sendiri tidak tahu akan keinginan dari anaknya serta para anak-anak sendiri menginginkan orang tua saling terbuka. Anak yang terbiasa mengekspresikan dirinya sendiri dengan apa adanya, memiliki freedom to be and to fail anvironment, akan lebih santai dalam menghadapi berbagai macam kesulitan dan hambatan karena biasanya membicarakan kepada orang tua, tanpa dibayang-bayangi rasa ketakutan, rasa malu, ataupun perasaan bersalah karena tidak mampunya sang remaja untuk memenuhi harapan dari orang tua (http://www.epsikologi.com).

Sejalan dengan pendapat Amato (2000:56), dalam jurnalnya The Consequences of Divorce For Adults And Children mengatakan bahwa anak-anak yang orang tuanya bercerai memiliki kelemahan dalam hal pencapaian akademik, tingkah laku, penyesuaian psikologis, konsep diri dan kompetensi sosial.

Dari observasi yang telah dilakukan terhadap siswa kelas XI Pemasaran 1 SMK Negeri 7 Medan Tahun Ajaran 2019/2020 yang terdiri dari 19 orang siswa yang memiliki orang tua tunggal dapat dilihat prestasi belajarnya yakni:

Tabel 1

Pengelompokan Prestasi Belajar Siswa

Kelas XI Pemasaran 1 SMK Negeri 7

Medan Tahun Ajaran 2019/2020

\begin{tabular}{|c|c|c|c|c|c|}
\hline Kelas & $\begin{array}{c}\text { Jumlah } \\
\text { Siswa } \\
\text { yang } \\
\text { memiliki } \\
\text { orang tua } \\
\text { tunggal }\end{array}$ & \multicolumn{2}{|c|}{$\begin{array}{c}\text { Siswa yang } \\
\text { memiliki } \\
\text { orang tua } \\
\text { tunggal } \\
\text { diatas } \\
\text { KKM }\end{array}$} & \multicolumn{2}{|c|}{$\begin{array}{c}\text { Siswa yang } \\
\text { memiliki } \\
\text { orang tua } \\
\text { tunggal } \\
\text { dibawah } \\
\text { KKM }\end{array}$} \\
\cline { 3 - 6 } & & $\begin{array}{c}\text { Ang } \\
\text { ka }\end{array}$ & $\begin{array}{c}\text { Pers } \\
\text { en }\end{array}$ & $\begin{array}{c}\text { Ang } \\
\text { ka }\end{array}$ & $\begin{array}{c}\text { Pers } \\
\text { en }\end{array}$ \\
\hline XI & 19 & 9 & $47 \%$ & 10 & $53 \%$ \\
PEMA & & & & & \\
SARA & & & & & \\
N 1 & & & & & \\
\hline
\end{tabular}

Sumber: Daftar Kumpulan Nilai (DKN) Siswa

Kelas XI Pemasaran 1 SMK Negeri 7 Medan

Tahun Ajaran 2019/2020. 
Dari data di atas menunjukkan bahwa siswa yang memiliki orang tua tunggal prestasi belajarnya dibawah KKM terdiri dari 10 orang dan siswa yang memiliki orang tua tunggal prestasi belajarnya diatas KKM terdiri dari 9 orang. Selain faktor pola komunikasi orang tua tunggal, faktor kedua yang dapat mempengaruhi prestasi belajar siswa yaitu kelompok teman sebayanya.

Kelompok teman sebaya merupakan lingkungan sosial atau kondisi di sekitar lingkungan siswa yang menjadi salah satu faktor yang dapat mempengaruhi prestasi belajar seseorang dari orang-orang yang seusia dan memiliki status yang sama dengan siapa seseorang umumnya berhubungan atau bergaul. Lingkungan sekolah tidak lepas dari dunia remaja, disekolah anak bertemu dengan teman-temannya, bermain dengan temantemannya. Tidak hanya disekolah, dirumah pun anak bergaul dengan teman sebayanya. Lingkungan sosial seperti para guru, para tenaga kependidikan (kepala sekolah dan wakil-wakilnya) dan teman-teman sekelas dapat mempengaruhi semangat belajar seorang siswa.

$$
\text { Kelompok teman sebaya }
$$
memungkinkan remaja belajar keterampilan sosial, mengembangkan minat yang sama, dan saling membantu dalam mengatasi kesulitan untuk mencapai kemandirian. Disamping itu, remaja menginginkan teman yang mempunyai minat dan nilai-nilai yang sama, yang dapat mengerti dan membuatnya merasa aman, dan yang kepadanya ia dapat mempercayakan masalah-masalah dan membahas hal-hal yang tidak dapat dibicarakan dengan orangtua maupun guru.

Menurut Slameto (2003:78), Interaksi atau relasi yang baik antara siswa yang satu dengan yang lainnya yang terjalin di dalam kelompok teman sebaya juga akan memberikan pengaruh terhadap belajar, karena dengan adanya relasi yang baik akan terciptanya suasana belajar yang lebih baik pula sehingga akan memberi dampak terhadap prestasi belajar siswa. Menciptakan relasi yang baik antar siswa adalah perlu, agar dapat memberikan pengaruh positif terhadap belajar siswa.

Salah satu permasalahan yang ada disekolah yaitu anak yang memiliki kelompok teman sebaya cenderung meniru sikap dari kelompok teman sebayanya seperti mencontek pada saat ujian, terlambat, bolos sekolah, tidak mengerjakan Pekerjaan Rumah (PR), tidak mendengarkan guru berbicara didepan, memainkan handphone ketika jam pelajaran dan melawan guru.

Berdasarkan pendapat diatas maka seharusnya tingkah laku dalam menjalin interaksi sosial yang ditampilkan oleh siswa di sekolah terhadap kelompok teman sebayanya harusnya baik, seperti saling bekerjasama, saling menghargai, saling membantu, dan saling menghormati.

Sejalan dengan pendapat Baihaqie (2011: 80) keberadaan kelompok teman sebaya diharapkan dapat dibentuk sebagai kelompok belajar dalam mencapai prestasi belajar yang lebih baik. peer group memberikan solusi 
kerangka berpikir kognitif, afektif dan psikomotorik dalam suasana aktifitas belajar yang kohesif sehingga terjadi perubahan belajar yang inovatif dan produktif dalam bentuk peningkatan kemampuan memecahkan masalah ataupun peningkatan prestasi belajar.

Dengan itu, kelompok teman sebaya pada siswa kelas XI Pemasaran 1 SMK Negeri 7 Medan yaitu:

Tabel 2

\section{Pengelompokan Kelompok Teman Sebaya}

Siswa Kelas XI Pemasaran 1 SMK Negeri 7

Medan Tahun Ajaran 2019/2020

\begin{tabular}{|c|c|c|c|c|c|}
\hline \multirow[t]{2}{*}{ Kelas } & \multirow[t]{2}{*}{$\begin{array}{c}\text { Jum } \\
\text { lah } \\
\text { Sisw } \\
\text { a }\end{array}$} & \multicolumn{2}{|c|}{$\begin{array}{c}\text { Siswa } \\
\text { yang } \\
\text { memiliki } \\
\text { kelompok } \\
\text { teman } \\
\text { sebaya }\end{array}$} & \multicolumn{2}{|c|}{$\begin{array}{c}\text { Siswa } \\
\text { yang tidak } \\
\text { memiliki } \\
\text { kelompok } \\
\text { teman } \\
\text { sebaya }\end{array}$} \\
\hline & & $\begin{array}{c}\text { An } \\
\text { gk } \\
\mathbf{a}\end{array}$ & $\begin{array}{c}\text { Pers } \\
\text { en }\end{array}$ & $\begin{array}{c}\text { An } \\
\text { gk } \\
\mathbf{a}\end{array}$ & $\begin{array}{c}\text { Pers } \\
\text { en }\end{array}$ \\
\hline $\begin{array}{c}\text { XI } \\
\text { PEMAS } \\
\text { ARAN 1 }\end{array}$ & 35 & 35 & $\begin{array}{c}100 \\
\%\end{array}$ & - & - \\
\hline
\end{tabular}

Sumber: Siswa Kelas XI Pemasaran 1 SMK

Negeri 7 Medan Tahun Ajaran 2019/2020.

Dari data di atas menunjukkan bahwa $100 \%$ siswa kelas XI Pemasaran 1 SMK Negeri 7 Medan Tahun Ajaran 2019/2020 memiliki kelompok teman sebaya yang 1 kelompok terdiri dari 4 sampai 9 orang didalamnya dan tidak ada siswa yang tidak memiliki kelompok teman sebaya.

Banyaknya kasus orang tua tunggal dan kelompok teman sebaya membuat peneliti ingin mengetahui lebih jauh bagaimana pengaruh pola komunikasi orang tua tunggal dan kelompok teman sebaya terhadap prestasi belajar. Dengan demikian, penelitian ini mengangkat tema "Pengaruh Pola Komunikasi Orang Tua Tunggal Dan Kelompok Teman Sebaya Terhadap Prestasi Belajar Siswa Kelas XI Pemasaran SMK Negeri 7 Medan Tahun Ajaran 2019/2020".

\section{TINJAUAN PUSTAKA}

\section{Prestasi Belajar}

Prestasi belajar merupakan hasil yang diperoleh dari proses belajar yang dijalani selama mengikuti proses pembelajaran. Prestasi belajar adalah bukti keberhasilan yang dapat dilihat dari perubahan-perubahan yang terdapat dalam diri seseorang mulai dari perubahan pengetahuan, pemahaman, keterampilan dan lain sebagainya.

Menurut Sudjana

(2005:22) berpendapat bahwa "hasil belajar adalah kemampuan-kemampuan yang dimiliki siswa setelah ia menerima pengalaman belajarnya". Syah (2008:88) memberikan pengertian bahwa Prestasi belajar merupakan pengungkapan hasil belajar ideal yang meliputi segenap ranah psikologis yang berubah sebagai akibat pengalaman dan proses belajar siswa. Sedangkan menurut Tirtonegoro (2001:43) "Prestasi belajar adalah penilaian hasil usaha kegiatan belajar yang dinyatakan dalam bentuk symbol, angka, huruf maupun kalimat yang dapat mencerminkan hasil yang sudah dicapai oleh setiap anak dalam periode tertentu".

$$
\text { Menurut Tirtonegoro }
$$

"Prestasi belajar adalah penilaian hasil usaha kegiatan belajar yang dinyatakan dalam bentuk 
simbol, angka, huruf maupun kalimat yang dapat mencerminkan hasil yang sudah dicapai oleh setiap anak dalam periode tertentu".

Berdasarkan pengertian-pengertian di atas dapat disimpulkan bahwa yang dimaksud dengan prestasi belajar adalah hasil yang telah dicapai dari usaha belajar siswa yang berupa penguasaan pengetahuan dan ketrampilan terhadap materi tertentu yang dinyatakan dalam bentuk angka, huruf maupun kalimat yang diberikan oleh guru dalam suatu periode tertentu.

\section{Pola Komunikasi Orang Tua Tunggal}

Menurut Yusuf (2004:13), terdapat tiga pola komunikasi didalam hubungan orang tua dengan anak, yaitu :

1. Authotarian (Cenderung bersikap bermusuhan)

Dalam pola hubungan ini sikap acceptance orang tua rendah, namun kontrolnya tinggi, suka menghukum secara fisik, bersikap mengkomando (mengharuskan/memeritah anak untuk melakukan sesuatu tanpa kompromi), bersika kaku (keras), cenderung emosional dan bersikap menolak. Sedangkan di pihak anak, anak mudah tersinggung, penakut, pemurung dan merasa tidak bahagia, mudah terpengaruh, stres, tidak mempunyai arah masa depan yang jelas tidak bersahabat. Sebagai contoh, orang tua yang otoriter mungkin berkata,"lakukanlah menurut caraku. Tidak ada diskusi!". Anakanak dari orang tua yang otoriter sering berperilaku dalam cara yang kurang kompeten secara sosial. Mereka cenderung khawatir tentang perbandingan sosial, gagal untuk memulai aktivitas dan mempunyai komunikasi yang buruk.

2. Permissive (Cenderung berprilaku bebas)

Dalam hal ini sikap acceptance orang tua tinggi, namun kontrolnya rendah, memberi kebebasan kepada anak untuk menyatakan dorongan atau keinginannya. Sedang anak bersikap impulsif serta agresif, kurang memiliki rasa percaya diri, suka mendominasi, tidak jelas arah hidupnya dan prestasinya rendah. Tidak semua orang tua dapat memahami pilihan anak remajanya. Bagi orang tua yang dapat memahami keinginan anaknya yang telah menginjak remaja, maka biasanya orang tua sejak awal telah membekali pendidikan, bimbingan dan arah yang baik agar anaknya berhati-hati dalam pergaulan dengan kelompok teman sebayanya. Akan tetapi ternyata banyak orang tua yang tidak memahami.

3. Authoritative (Cenderung terhindar dari kegelisahan dan kekacauan)

Dalam hal ini acceptance orang tua dan kontrolnya tinggi, bersikap responsif terhadap kebutuhan anak, mendorong anak untuk menyatakan pendapat atau pertanyaan, memberi penjelasan tentang dampak perbuatan yang baik dan buruk. Sedangkan anak bersikap bersahabat, memiliki rasa percaya diri, mampu mengendalikan diri (self control) bersikap sopan, mau bekerja sama, memiliki rasa ingin tahunya tinggi, mempunyai tujuan/arah hidup yang jelas dan berorientasi pada prestasi. Orang tua otoritatif mungkin memeluk 
anaknya dengan cara yang menyenangkan dan berkata,"Kamu tahu kamu seharusnya tidak boleh melakukan hal itu. Mari kita bicarakan tentang bagaimana kamu bisa menangani situasi itu secara berbeda di kemudian hari”. Anak-anak yang memiliki orang tua otoritatif sering berperilaku dalam cara yang kompeten secara sosial. Mereka cenderung percaya diri, dapat menunda keinginan, akrab dengan dengan teman-teman sebayanya, dan menunjukkan harga diri yang tinggi.

Berdasarkan pengertian-pengertian di atas dapat disimpulkan bahwa yang dimaksud dengan Pola Komunikasi Orang Tua Tunggal ada tiga pola yaitu pola Authotarian (Cenderung bersikap bermusuhan), pola Permissive (Cenderung berprilaku bebas) dan pola Authoritative (Cenderung terhindar dari kegelisahan dan kekacauan)

\section{Kelompok Teman Sebaya}

Menurut Johnson (Sarwono, 2005:23):

Kelompok adalah kumpulan dua orang individu atau lebih yang berinteraksi tatap muka, yang masing-masing menyadari keanggotaanya dalam kelompok, masingmasing menyadari keberadaan orang lain yang juga anggota kelompok dan masing-masing menyadari saling ketergantungan secara positif dalam mencapai tujuan bersama.

Hal tersebut sesuai dengan pernyataan Bonner dalam Shaw (1979:10):

A group is a number of people in interaction with one another, and it is this interaction process that distinguishes group from an aggregate, yang artinya teman sebaya merupakan kelompok atau kumpulan yang saling mengisi satu sama lain mempunyai hobi atau kesamaan-kesamaan yang lainnya dan mempunyai usia yang hampir sama.

Menurut Ivor Morrish dalam Abu Ahmadi (2004:191):

A peer is an equel, and a peer group is a group composed of individuals who are equales, yang artinya teman sebaya adalah teman yang memiliki persamaan, dan kelompok sebaya adalah suatu kelompok yang terdiri dari individu-individu yang sama. Pengertian sama disini berarti individuindividu anggota kelompok teman sebaya tersebut memiliki kesamaan dalam berbagai aspek. Persamaan yang menjadi aspek utamanya adalah kesamaan usia dan status sosialnya.

Dari pengertian diatas maka kelompok teman sebaya adalah kelompok persahabatan yang mempunyai nilai-nilai dan pola hidup sendiri, di mana persahabatan dalam periode teman sebaya penting sekali karena merupakan dasar primer mewujudkan nilai-nilai dalam suatu kontak sosial. Di samping itu juga mempraktekkan berbagai prinsip kerja sama, tanggungjawab bersama, persaingan yang sehat dan sebagainya. Jadi kelompok teman sebaya merupakan media bagi anak untuk mewujudkan nilai-nilai sosial tersendiri dalam melakukan prinsip kerjasama, tanggungjawab dan kompetisi.

\section{METODE PENELITIAN}

\section{Lokasi dan Waktu Penelitian}


Penelitian ini dilakukan di SMK Negeri 7 Medan terletak di Jl. STM No.12E Medan, Siti Rejo II, Kec. Medan Amplas, Kota Medan. Penelitian ini dilaksanakan pada semester ganjil tahun pembelajaran 2019/2020.

\section{Populasi dan Sampel Penelitian}

Populasi dalam penelitian ini adalah seluruh siswa kelas XI Pemasaran di SMK Negeri 7 Medan Tahun Ajaran 2019/2020 yang terdiri dari 2 kelas yaitu kelas XI PEMASARAN 1 dan kelas XI PEMASARAN 2.

Sampel dalam penelitian ini adalah seluruh siswa kelas XI Pemasaran di SMK Negeri 7 Medan Tahun Ajaran 2019/2020 yang berjumlah 33 orang yang memiliki orang tua tunggal dan kelompok teman sebaya (total sampling). Maka penelitian ini dinamakan penelitian populasi

\section{Teknik Pengumpulan Data}

Teknik pengumpulan data dalam penelitian ini adalah dengan cara observasi, penyebaran angket dan dokumentasi.

\section{Teknik Analisis Data}

Analisis data bertujuan untuk mengolah data agar penelitian dapat dipertanggungjawabkan kebenarannya.

\section{Uji Instrumen}

Uji intrumen dalam penelitian ini menggunakan uji validitas dan uji reliabilitas terhadap angket.
- Uji Validitas pada pnelitian ini menggunakan rumus korelasi Produk Moment

$$
r_{x y}=\frac{N \sum(X Y)-\sum(X)\left(\sum(Y)\right.}{\sqrt{\left\{N \sum X^{2}-\left(\sum X\right)^{2}\right\}}}
$$

(Arikunto, $2014: 213$ )

$\mathrm{r}^{\mathrm{xy}} \quad=$ Koefisien korelasi antara variabel $\mathrm{x}$ dan y

$\sum \mathrm{X}=$ Jumlah skor variabel $\mathrm{X}$

$\sum \mathrm{Y}=$ Jumlah skor variabel $\mathrm{Y}$

$\sum X Y=$ Jumlah skor variabel $\mathrm{XY}$

$\sum \mathrm{X}^{2}=$ Jumlah skor variabel $\mathrm{X}^{2}$

$\sum \mathrm{Y}^{2}=$ Jumlah skor variabel $\mathrm{Y}^{2}$

$\mathrm{N} \quad=$ Jumlah responden atau banyaknya sampel

Syarat valid apabila $r_{\text {hitung }}>r_{\text {tabel }}$ dengan taraf signifikan 95\% ( $\alpha=5 \%)$ maka instrument itu dianggap valid dan jika $\mathrm{r}_{\text {hitung }}<\mathrm{r}_{\text {tabel }}$ pada taraf signifikan $95 \%(\alpha=5 \%)$ maka instrument tersebut dianggap tidak valid.

- Untuk menguji reliabilitas instrument dapat dihitung dengan menggunakan rumus alpha, seperti yang dikemukakan Arikunto (2014: 239) :

$$
r_{11}=\left[\frac{k}{k-1}\right]\left[1-\frac{\sum \sigma_{b}^{2}}{\sigma_{t}^{2}}\right]
$$

Keterangan :

r11 = Reliabilitas instrumen

$\mathrm{k}=$ Banyaknya butir pertanyaan atau banyaknya soal

$\sum \sigma_{b}^{2}=$ Jumlah varians butir

$\sum \sigma_{t}^{2}=$ varians total

Untuk mencari varians butir soal digunakan rumus:

$$
\sigma_{b}^{2}=\frac{\sum x^{2}-\left(\frac{\sum x}{N}\right)^{2}}{N}
$$


Keterangan :

$\mathrm{N}=$ Jumlah responden

$\sum \mathrm{X}=$ Jumlah skor variabel $\mathrm{X}$

$\sum \mathrm{X}^{2}=$ Jumlah skor kuadrat variabel $\mathrm{X}$

Untuk mencari varians total

digunakan rumus:

$$
\sigma_{t}^{2}=\frac{\sum Y^{2}-\left(\frac{\sum Y}{N}\right)^{2}}{N}
$$

Keterangan :

$\mathrm{N}=$ Jumlah responden/sampel

$\sum \mathrm{Y} \quad=$ Banyaknya skor total subjek

$\sum \mathrm{Y}^{2}=$ Jumlah skor kuadrat skor total

subjek

Dengan ketentuan jika $r_{\text {hitung }}>r_{\text {tabel }}$ signifikan 95\% ( $\alpha=5 \%)$ maka dapat dikatakan reliabel, selanjutnya jika $r_{\text {hitung }} \leq r_{\text {tabel }}$, maka instrument dianggap tidak reliabel.

\section{Uji Asumsi Klasik}

Sebelum melakukan analisis regresi linear berganda, terebih dahulu dilakukan analisis dengan menggunakan uji asumsi klasik yang meliputi uji normalitas, uji linearitas dan uji multikolinearitas terhadap data. Adapun langkah-langkah melakukan analisis data adalah sebagai berikut:

\section{a. Uji Normalitas}

Tujuan dilakukannya uji normalitas adalah ingin mengetahui apakah distribusi sebuah data mengikuti atau mendekati distribusi normal. Data yang baik adalah data yang mempunyai pola seperti distribusi normal. Deteksi normalitas dilakukan dengan dilakukan dengan melihat grafik Normal Probability Plot.

Kriteria pengambilan keputusannya adalah sebagai berikut :
1. Jika data menyebar disekitar garis diagonal dan mengikuti arah garis diagonal maka model regresi asumsi normalitas.

2. Jika data menyebar jauh dari garis diagonal dan atau tidak mengikuti arah garis diagonal maka model regresi tidak memenuhi asumsi normalitas.

\section{b. Uji Linieritas}

Tujuan dilakukan uji linearitas data adalah untuk mengetahui apakah hubungan antar variabel bebas dan variabel terikatnya linear. Variabel dikatakan mempunyai hubungan linear apabila signifikansi Linearity kurang dari 0,05 ( $\mathrm{p}$ value $<0,05$ ) sedangkan nilai signifikansi Deviation of Linearity lebih besar dari 0,05 ( $\mathrm{p}$ value > 0,05). Kriteria lain yang digunakan adalah dengan uji F. Apabila nilai sig $\mathrm{F}$ tersebut kurang dari 0,05 maka hubungannya tidak linear, sedangkan jika nilai sig F lebih besar dari atau sama dengan 0,05 maka hubungannya linear.

\section{c. Uji Multikolinieritas}

Uji multikolinieritas bertujuan untuk menguji apakah pada model regresi ditemukan adanya korelasi antar variabel bebas. Model regresi yang baik seharusnya tidak terjadi multikolinearitas. Suatu model regresi dikatakan tidak terjadi multikolinearitas apabila nilai Varians Inflation Factor (VIF) < 10 dan nilai Tolerance > 0,1. Dalam pengolahannya penulis meggunakan bantuan program IBM SPSS Statistic 21. 


\section{Analisis Regresi Linier Berganda}

Analisis regresi linear berganda digunakan untuk meramalkan bagaimana keadaan (naik turunnya) variabel- variabel dependen, bila dua atau lebih variabel independen sebagai faktor prediktor dimanipulasi (dinaik turunkan nilainya). Jadi analisis regresi linear berganda digunakan bila jumlah variabel independennya minimal 2 . Model ini digunakan untuk mengetahui pengaruh Pola Komunikasi Orang Tua Tunggal $\left(\mathrm{X}_{1}\right)$ dan Kelompok Teman Sebaya $\left(\mathrm{X}_{2}\right)$ terhadap Prestasi Belajar $(\mathrm{Y})$.

Persamaan regresi linear berganda sebagai berikut :

$Y^{\prime}=\alpha+\beta_{1} X_{1}+\beta_{2} X_{2}+e$

Keterangan :

$\mathrm{Y}^{\prime}=$ Prestasi belajar

$\mathrm{X}_{1}=$ Pola Komunikasi Orang Tua Tunggal

$\mathrm{X}_{2}=$ Kelompok Teman Sebaya

\section{Uji Hipotesis}

\section{a. Uji t (Uji Parsial)}

Pengujian Hipotesis Secara Parsial

(Uji t) dalam penelitian ini menggunakan rumus:

$$
\boldsymbol{t}_{\text {regrest }}=\frac{\boldsymbol{b}_{i}-\boldsymbol{\beta}_{i}}{S b i}
$$

Keterangan:

$\mathrm{b}_{\mathrm{i}} \quad=$ koefisien regresi variabel

$\mathrm{Sb}_{\mathrm{i}}=$ Standar error/kesalahan standar koefisien regresi variabel $\left(b_{i}\right)$

$\beta \mathrm{i}=$ koefisien beta/parameter ke-I dihipotesiskan

\section{b. Uji Simultan (Uji F)}

Sedangkan pengujian hipotesis secara simultan (Uji F) dalam penelitian ini menggunakan:

$$
\boldsymbol{F}_{h}=\frac{\boldsymbol{R}^{2 / k}}{\left(1-\boldsymbol{R}^{2}\right) /(n-k-1)}
$$

Keterangan:

$\mathrm{R} \quad=$ koefisien determinasi

$\mathrm{k} \quad=$ jumlah variabel independen

$\mathrm{n} \quad=$ jumlah anggota sampel

Pengujian hipotesis diambil berdasarkan probabilitas (Pratisto, 2004) dengan cara:

a. Jika probabilitas > 0,05 maka Ho diterima dan $\mathrm{Ha}$ ditolak berarti tidak terdapat perbedaan yang signifikan antara pola komunikasi orang tua tunggal dan kelompok teman sebaya.

b. Jika probabilitas $<0,05$ maka Ho ditolak dan $\mathrm{Ha}$ diterima terdapat perbedaan yang signifikan pola komunikasi orang tua tunggal dan kelompok teman sebaya

\section{c. Koefisien Determinasi $\left(\mathbf{R}^{2}\right)$}

Determinasi digunakan untuk mengetahui persentase sumbangan pengaruh variabel independen terhadap variabel dependen. Untuk mengetahui besarnya pengaruh pola komunikasi orang tua tunggal dan kelompok teman sebaya terhadap prestasi belajar siswa maka koefisien determinasi $\mathrm{R}^{2}$ dapat ditentukan oleh rumus:

$$
K P=R_{y(1,2)}^{2}=\frac{b_{1}\left(X_{1 i} Y_{i}\right)+b_{2}\left(X_{2 i} Y_{i}\right)}{\sum Y_{i}^{2}}
$$

Keterangan :

$\mathrm{KP}=$ Koefisien determinasi

$\mathrm{X}=$ Variabel bebas 
$\mathrm{Y}=$ Variabel terikat

$\mathrm{b}=$ Koefisien regresi variabel $\mathrm{X}$ terhadap Y

\section{HASIL DAN PEMBAHASAN}

\section{Hasil Penelitian}

\section{Uji Instrumen Penelitian}

Setelah uji coba, pada variabel pola komunikasi orang tua tunggal sebanyak 26 butir soal dan hasilnya 19 butir soal tersebut valid dan reliabel yang dapat digunakan untuk penelitian. Untuk jumlah responden 33 siswa dengan taraf signifikan $95 \%$ dan alpha $5 \%$ serta nilai $r_{\text {tabel }} \quad 0,3882$. Pada variabel kelompok teman sebaya dari 26 butir soal hasilnya 20 butir soal tersebut valid dan reliabel yang dapat digunakan untuk penelitian. Untuk jumlah responden 30 dengan taraf signifikan 95\% dan alpha 5\% nilai $r_{\text {tabel }} 0,3882$.

\section{Uji Asumsi Klasik}

\section{a. Uji Normalitas}

Tabel 3

Uji Normalitas

One-Sample Kormogarov-Smirnov Test

\begin{tabular}{|ll|r|}
\hline & & \multicolumn{2}{|c|}{$\begin{array}{c}\text { Unstandardized } \\
\text { Residual }\end{array}$} \\
\hline $\mathrm{N}$ & Mean &, 0000000 \\
& Std. & 1,19025107 \\
Normal & Parameters & \\
& Deviation & Absolute \\
Most Extreme & Positive \\
Differences & Negative &, 058 \\
& Kolmogorov-Smirnov Z &,- 082 \\
Asymp. Sig. & &, 470 \\
\hline
\end{tabular}

(2-tailed)

a. Test distribution is Normal.

b. Calculated from data.

Sumber : pengolahan data dengan spss 21

Dari hasil uji normalitas menggunakan analisis uji Kolmogorov- Smirnov pada SPSS diatas, yaitu nilai Asymp.Sig.(2 tailed) nilainya $0,980>0,05$ yang artinya data berdistribusi normal.

\section{b. Uji Linearitas}

Tujuan Uji linearitas dilakukan adalah untuk mengetahui hubungan antara variabel bebas dan variabel terikat. Kriteria yang digunakan untuk melihat hubungan antar variabel (linearitas) dapat diketahui dengan melihat nilai signifikansinya (deviation from linearity). Jika nilai signifikan > 0,05 artinya terdapat hubungan yang linear, sebaliknya jika nilai signifikan $<0,05$ maka tidak terdapat hubungan yang linear. Setelah dilakukan pengujian linearitas dengan menggunakan program SPSS 21 maka diperoleh linearitas dengan nilai signifikansi Deviation From Linearity adalah $0,080(0,080>0,05)$. Artinya ada hubungan linear secara signifikan antara variabel pola komunikasi orang tua tunggal $\left(\mathrm{X}_{1}\right)$ terhadap prestasi belajar (Y) yang digunakan dalam penelitian ini.

Kemudian kelompok teman sebaya $\left(\mathrm{X}_{2}\right)$ diperoleh linearitas dengan nilai signifikansi Deviation From Linearity adalah $0,840(0,840>0,05)$. Artinya ada hubungan linear antara variabel kelompok teman sebaya $\left(\mathrm{X}_{2}\right)$ terhadap prestasi belajar (Y) yang digunakan dalam penelitian ini. 
Dengan demikian dapat disimpulkan bahwa kedua variabel bebas cukup baik digunakan dalam model regresi dan pengujian selanjutnya.

\section{c. Uji Multikolinieritas}

Uji multikolinearitas digunakan untuk melihat apakah terdapat hubungan antara variabel bebas dalam penelitian. Penelian yang baik adalah ketika tidak terjadi multikolinearitas antar variabel bebas yaitu ketika nilai Tolerance lebih besar dari 0,1 dan nilai VIF lebih kecil dari 10. Untuk lebih jelas uji multikolinearitas dalam penelitian diketahui bahwa nilai tolerance variabel pola komunikasi orang tua tunggal dan kelompok teman sebaya yaitu $0,962>0,1$ dan nilai VIF $1,039<10$. Hal ini berarti bahwa kedua variabel bebas tidak saling memiliki hubungan dan baik digunakan untuk model regresi. Sehingga dapat disimpulkan bahwa tidak terjadi multikolinearitas.

\section{Analisis Regresi Linear Berganda}

Tabel 4

\section{Analisis Regresi Linear Berganda}

coefficients $^{\mathrm{a}}$

\begin{tabular}{|c|c|c|c|c|c|c|c|}
\hline \multirow[t]{2}{*}{ Model } & \multicolumn{2}{|c|}{$\begin{array}{c}\text { Unstand } \\
\text { ar dized } \\
\text { Coeffici } \\
\text { e } \\
\mathrm{Nts}\end{array}$} & \multirow{2}{*}{$\begin{array}{c}\text { Stan } \\
\text { dar } \\
\text { dize } \\
\text { d } \\
\text { Coef } \\
\text { fici } \\
\text { e } \\
\text { nt } \\
\text { s } \\
\text { Bet } \\
\text { a }\end{array}$} & \multirow[t]{2}{*}{$\mathrm{T}$} & \multirow[t]{2}{*}{$\begin{array}{l}\mathrm{Si} \\
\mathrm{g} .\end{array}$} & \multicolumn{2}{|c|}{$\begin{array}{l}\text { Collinea } \\
\text { rit y } \\
\text { Statistic } \\
\text { S }\end{array}$} \\
\hline & B & $\begin{array}{c}\text { Std } \\
\text { Err } \\
\text { or }\end{array}$ & & & & $\begin{array}{l}\text { To } \\
\text { ler } \\
\text { an } \\
\text { ce }\end{array}$ & $\begin{array}{l}\text { VI } \\
\text { F }\end{array}$ \\
\hline $\begin{array}{l}\text { (Consta } \\
\mathrm{nt})\end{array}$ & $\begin{array}{r}85,4 \\
61\end{array}$ & $\begin{array}{l}5,5 \\
23\end{array}$ & & $\begin{array}{l}15, \\
47\end{array}$ & $\begin{array}{l}, 0 \\
00\end{array}$ & & \\
\hline
\end{tabular}

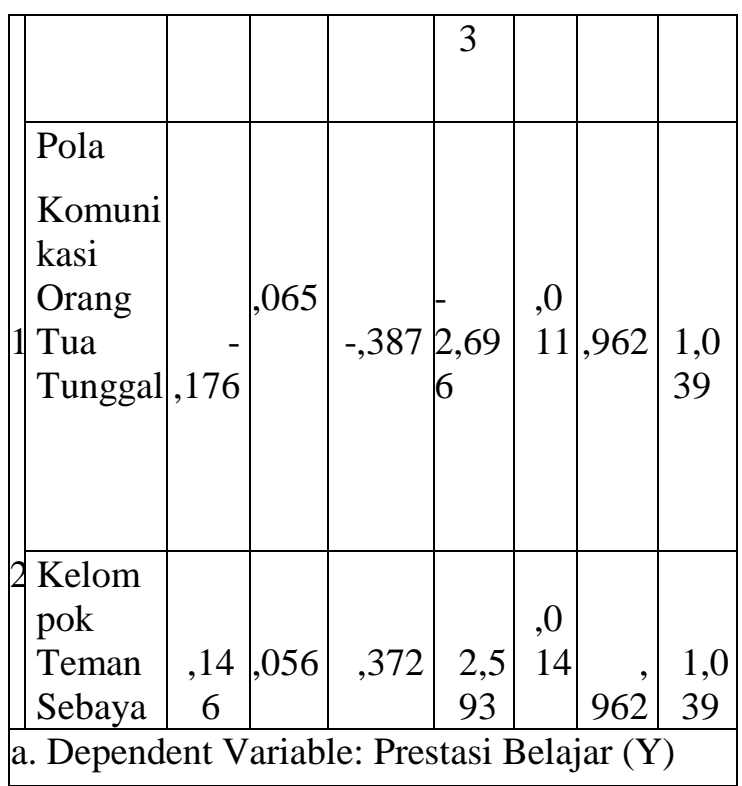

Dari tabel diatas diperoleh persamaan regresi linear berganda sebagai berikut:

$\mathrm{Y}=85,461-0,176 \mathrm{X}_{1}+0,146 \mathrm{X}_{2}+\mathrm{e}$

Penjelasan persamaan tersebut sebagai berikut

a. Nilai Konstanta (a) sebesar 85,461 artinya jika variabel Komunikasi Orang Tua Tunggal $\left(\mathrm{X}_{1}\right)$ dan Kelompok Teman Sebaya $\left(\mathrm{X}_{2}\right)$ dianggap tidak ada atau sama dengan 0 (nol), maka Prestasi Belajarsiswa kelas XI Pemasaran SMK Negeri 7 Medan T.A 2019/2020 memiliki nilai sebesar 85,461.

b. Nilai Koefisien regresi variabel Pola Komunikasi Orang Tua Tunggal $\left(\mathrm{X}_{1}\right)$ sebesar -0,176. Artinya jika variabel Pola Komunikasi Orang Tua Tunggal $\left(\mathrm{X}_{1}\right)$ mengalami peningkatan sebesar $1 \%$, sementara variabel Kelompok Teman Sebaya $\left(\mathrm{X}_{2}\right)$ dianggap konstan, maka akan menyebabkan penurunan pada variabel Prestasi Belajar siswa sebesar 0,176.

c. Nilai Koefisien regresi variabel Kelompok Teman Sebaya $\left(\mathrm{X}_{2}\right)$ sebesar 0,146. 
Artinya jika variabel Kelompok Teman Sebaya $\left(\mathrm{X}_{2}\right)$ mengalami peningkatan sebesar $1 \%$, sementara variabel Pola Komunikasi Orang Tua Tunggal ( $\left.\mathrm{X}_{1}\right)$ dianggap konstan, maka akan menyebabkan kenaikan pada variabel Prestasi Belajar siswa sebesar 0,146.

\section{Uji Hipotesis}

\section{a. Uji t (Uji Parsial)}

Hasil perhitungan uji hipotesis secara parsial (Uji t) diperoleh nilai $t_{\text {tabel }}$ sebesar 2,042, pada taraf signifikan 95\%, $\alpha=5 \%$ dengan $\mathrm{df}=\mathrm{n}-\mathrm{k}-1(33-2-1=30)$ maka berdasarkan tabel analisis regresi linier berganda diatas menunjukkan bahwa untuk variabel Pola Komunikasi Orang Tua Tunggal $\left(\mathrm{X}_{1}\right)$, diperoleh $\mathrm{t}_{\text {hitung }}$ sebesar 2,696, dan nilai signifikan sebesar 0,011. Hal ini menunjukkan bahwa $t_{\text {hitung }}>t_{\text {tabel }}$ dimana 2,696 > 2,042 dan nilai signifikan $\alpha(0,011<0,05)$. Maka dapat dikatakan bahwa secara parsial, terdapat pengaruh (negatif) dan signifikan antara variabel Pola Komunikasi Orang Tua Tunggal $\left(\mathrm{X}_{1}\right)$ terhadap Prestasi Belajar siswa kelas XI Pemasaran SMK Negeri 7 Medan T.A 2019/2020.

Hasil perhitungan uji hipotesis secara parsial (Uji t) diperoleh nilai $t_{\text {tabel }}$ sebesar 2,042, pada taraf signifikan 95\%, $\alpha=5 \%$ dengan $\mathrm{df}=\mathrm{n}-\mathrm{k}-1(33-2-1=30)$ maka berdasarkan tabel analisis regresi linier berganda diatas menunjukkan bahwa untuk variabel Kelompok Teman Sebaya $\left(X_{2}\right)$, diperoleh $t_{\text {hitung }}$ sebesar 2,593, dan nilai signifikan sebesar 0,014. Hal ini menunjukkan bahwa $t_{\text {hitung }}>t_{\text {tabel }}$ dimana $2,593>2,042$ dan nilai signifikan $\alpha(0,014<0,05)$. Maka dapat dikatakan bahwa secara parsial, terdapat pengaruh (positif) dan signifikan antara variabel Kelompok Teman Sebaya $\left(\mathrm{X}_{2}\right)$ terhadap Prestasi Belajar siswa kelas XI Pemasaran SMK Negeri 7 Medan T.A 2019/2020.

\section{b. Uji Simultan (uji F)}

Untuk membuktikan kebenaran hipotesis secara keseluruhan (simultan) digunakan uji F. Berikut tabel pengujian uji $\mathrm{F}$

\section{Tabel 5 Uji F}

\section{ANOVA $^{\mathrm{a}}$}

\begin{tabular}{|l|r|r|r|r|r|}
\hline Model & $\begin{array}{c}\text { Sum } \\
\text { of } \\
\text { Square } \\
\text { s }\end{array}$ & $\begin{array}{c}\text { df } \\
\text { Sean } \\
\text { Squar } \\
\mathrm{e}\end{array}$ & $\mathrm{F}$ & Sig. \\
\hline Regressio & 32,601 & 2 & 16,30 & 3,56 &, 041 \\
$\mathrm{n}$ & & 1 & 2 & $\mathrm{~b}$ \\
1 Residual & $\begin{array}{r}137,27 \\
7\end{array}$ & 0,576 & & \\
Total & 169,87 & 3 & & & \\
\hline
\end{tabular}

a. Dependent Variable: Prestasi Belajar (Y)

b. Predictors: (Constant), Kelompok Teman Sebaya $\left(\mathrm{X}_{2}\right)$, Pola Komunikasi Orang Tua Tunggal $\left(\mathrm{X}_{1}\right)$

Berdasarkan hasil pengolahan data dengan menggunakan program SPSS 21 dari tabel diatas diperoleh $F_{\text {hitung }}$ sebesar 3,562 dengan taraf signifikan 0,041 dan $\mathrm{F}_{\text {tabel }}$ sebesar 3,32 diketahui dari df 1 (pembilang) $=$ jumlah variabel $-1(3-1=2)$ dan df 2 (penyebut) $=\mathrm{n}-$ $\mathrm{k}-1(30-2-1=30)$ Sehingga dapat disimpulkan bahwa terdapat pengaruh positif dan signifikan antara variabel Pola Komunikasi Orang Tua Tunggal $\left(\mathrm{X}_{1}\right)$ dan 
Kelompok Teman Sebaya $\left(\mathrm{X}_{2}\right)$ terhadap Prestasi Belajar (Y) siswa kelas XI Pemasaran SMK Negeri 7 Medan T.A 2019/2020.

\section{c. Koefisien Determinasi $\left(\mathbf{R}^{2}\right)$}

Uji koefisien determinasi

digunakan untuk mengetahui bagaimana kontribusi atau kemampuan variabel bebas dalam menerangkan variabel terikat. Berikut tabel hasil perhitungan koefisien determinasi.

\section{Tabel 6 Uji R ${ }^{2}$}

Model Summary ${ }^{b}$

\begin{tabular}{|l|c|r|r|r|}
\hline Model & $\mathrm{R}$ & $\begin{array}{c}\mathrm{R} \\
\text { Square }\end{array}$ & $\begin{array}{r}\text { Adjusted } \\
\text { R Square }\end{array}$ & $\begin{array}{c}\text { Std. Error } \\
\text { of the } \\
\text { Estimate }\end{array}$ \\
\hline 1 &, $698^{\mathrm{a}}$ &, 548 &, 538 & 2,971 \\
\hline
\end{tabular}

a. Predictors: (Constant), Kelompok Teman

Sebaya $\left(\mathrm{X}_{2}\right)$, Pola Komunikasi Orang Tua

Tunggal $\left(\mathrm{X}_{1}\right)$

b. Dependent Variable: Prestasi Belajar (Y)

Dari output diatas nilai $\mathrm{R}$ Square sebesar 0,548 atau $54,8 \%$. Hal ini menunjukkan bahwa variabel Pola Komunikasi Orang Tua Tunggal $\left(\mathrm{X}_{1}\right)$ dan Kelompok Teman Sebaya $\left(\mathrm{X}_{2}\right)$ secara bersama-sama memiliki kontribusi terhadap Prestasi Belajar siswa kelas XI Pemasaran SMK Negeri 7 Medan T.A 2019/2020 yaitu sebesar 54,8\% dan sisanya sebesar 45,2\% dipengaruhi oleh faktor lain diluar dari faktor penelitian yang tidak dimasukkan dalam model penelitian ini.

\section{Pembahasan Hasil Penelitian}

Data dalam penelitian ini diperoleh dengan cara menyebarkan kuesioner kepada para siswa kelas XI Pemasaran SMK Negeri 7 Medan Tahun Ajaran 2019/2020. Penelitian ini bertujuan untuk mengetahui Pengaruh Pola Komunikasi Orang Tua Tunggal Dan Kelompok Teman Sebaya Terhadap Prestasi Belajar Siswa Kelas XI Pemasaran SMK Negeri 7 Medan Tahun Ajaran 2019/ 2020. Analisis yang digunakan dalam penelitian ini adalah analisis regresi linier berganda.

Berdasarkan jawaban responden pada variabel pola komunikasi orang tua tunggal yang dilakukan terhadap 33 siswa disekolah diperoleh hasil analisis regresi linier berganda dengan hasil yang menyatakan bahwa variabel pola komunikasi orang tua tunggal berpengaruh yang negatif dan signifikan terhadap prestasi belajar. Hal ini sesuai dengan pendapat Amato (2000:56), bahwa anak-anak yang orang tuanya bercerai atau meninggal dunia memiliki kelemahan dalam hal pencapaian akademik. Hasil penelitian ini juga didukung penelitian yang sebelumnya telah dilakukan oleh Putri (2016:11) dengan judul "pola komunikasi single parent dalam mendidik anak" hasil penelitian dalam wawancara menunjukkan bahwa 3 dari 5 siswa yang orang tuanya tunggal masih menggunakan pola permissive (cenderung berperilaku bebas) dikarenakan orang tuanya sibuk mencari uang dan ia menjadi tidak jelas hidupnya karena kurangnya perhatian dari orang tua.

Selain itu berdasarkan jawaban responden pada variabel kelompok teman sebaya yang dilakukan terhadap responden diperoleh hasil regresi linier berganda dengan hasil yang menyatakan bahwa variabel kelompok teman sebaya berpengaruh yang 
positif dan signifikan terhadap prestasi belajar. Hal ini sesuai dengan pendapat Baihaqie (2011:80), Keberadaan kelompok teman sebaya diharapkan dapat dibentuk sebagai kelompok belajar dalam mencapai prestasi belajar yang lebih baik. Kelompok teman sebaya memberikan solusi kerangka berfikir kognitif, afektif dan psikomotorik dalam suasana aktifitas belajar yang kohesif sehingga terjadi perubahan belajar yang inovatif dan produktif dalam bentuk peningkatan kemampuan memecahkan masalah ataupun peningkatan prestasi belajar siswa. Hasil penelitian ini juga didukung penelitian yang sebelumnya telah dilakukan oleh Aziz (2015:10) dengan judul "hubungan antara kelompok teman sebaya dengan prestasi belajar siswa smkn 8 bandung" hasil penelitian menunjukkan bahwa $t_{\text {hitung }}>t_{\text {tabel }}$ yaitu 2,251 > 1,668, hal ini menunjukkan bahwa kelompok teman sebaya berpengaruh positif dan signifikan terhadap prestasi belajar siswa smkn 8 bandung.

Berdasarkan penelitian yang telah dilakukan, dapat disimpulkan bahwa variabel pola komunikasi orang tua tunggal dan kelompok teman sebaya berpengaruh signifikan terhadap prestasi belajar. Hal ini ditunjukkan dengan hasil pengujian dengan uji $F$ diperoleh hasil bahwa nilai $F_{\text {hitung }}$ sebesar 3,562 dan $F_{\text {tabel }} 3,32$. Maka $F_{\text {hitung }}>F_{\text {tabel }}(3,562$ $>3,32$ ) dengan taraf signifikan 0,041 < 0,05. Dengan adanya pola komunikasi orang tua tunggal yang baik dengan anaknya akan memberikan pencapaian akademik yang baik pula karena didalam keluarga komunikasi apapun akan mempengaruhi proses pertumbuhan dan perkembangan anak dalam segi apapun. Selain itu juga fungsi utama keluarga yaitu sebagai wahana komunikasi, mendidik dan mensosialisasikan anak dalam masyarakat serta mengembangkan kemampuannya karena anak dapat leluasa menyampaikan pendapat, saling bertukar pikiran, belajar bersama dan memiliki minat yang sama dan dengan adanya kelompok teman sebaya memberikan solusi kerangka berfikir kognitif, afektif dan psikomotorik dalam suasana aktifitas belajar yang kohesif sehingga terjadi perubahan belajar yang inovatif dan produktif dalam bentuk peningkatan kemampuan memecahkan masalah ataupun peningkatan prestasi belajar siswa.

\section{KESIMPULAN DAN SARAN}

Berdasarkan data yang diperoleh dan hasil pengujian/analisis yang telah dilakukan, maka kesimpulan yang dapat diberkan dalam penelitian ini adalah sebagai berikut:

Koefisien $\mathrm{X}_{1}$ sebesar 0,176 yang artinya apabila variabel Pola Komunikasi Orang Tua Tunggal $\left(\mathrm{X}_{1}\right)$ mengalami peningkatan sebesar $1 \%$, sementara variabel Kelompok Teman Sebaya $\left(\mathrm{X}_{2}\right)$ dianggap konstan, maka akan menyebabkan penurunan pada variabel Prestasi Belajar siswa sebesar 0,176. Lalu nilai koefisien variabel Kelompok Teman Sebaya $\left(\mathrm{X}_{2}\right)$ sebesar 0,146. Artinya jika variabel Kelompok Teman Sebaya $\left(\mathrm{X}_{2}\right)$ mengalami peningkatan sebesar $1 \%$, sementara variabel Pola Komunikasi Orang Tua Tunggal 
$\left(\mathrm{X}_{1}\right)$ dianggap konstan, maka akan menyebabkan kenaikan pada variabel Prestasi Belajar siswa sebesar 0,146.

Berdasarkan hasil dari pengujian koefisien regresi secara parsial bahwa Pola Komunikasi Orang Tua Tunggal $\left(\mathrm{X}_{1}\right)$ memiliki pengaruh negatif dan signifikan terhadap prestasi belajar siswa kelas XI Pemasaran SMK Negeri 7 Medan T.A 2019/2020. Dimana, $t_{\text {hitung }}$ sebesar $-2,696$, $t_{\text {tabel }}$ sebesar 2,042 dan nilai signifikan sebesar 0,011. Hal ini menunjukkan bahwa $t_{\text {hitung }}>t_{\text {tabel }}$ yaitu 2,696 $>$ 2,042 dan nilai signifikan $\alpha(0,011<0,05)$. Selanjutnya pada variabel Kelompok Teman Sebaya $\left(\mathrm{X}_{2}\right)$ Memiliki pengaruh positif dan signifikan terhadap prestasi belajar siswa kelas XI Pemasaran SMK Negeri 7 Medan T.A 2019/2020. Dimana, $t_{\text {hitung }}$ sebesar 2,593, $t_{\text {tabel }}$ sebesar 2,042 dan nilai signifikan sebesar 0,014 . Hal ini menunjukkan bahwa $t_{\text {hitung }}>t_{\text {tabel }}$ yaitu 2,593> 2,042 dan nilai signifikan $\alpha$ $(0,014<0,05)$.

Berdasarkan hasil pengujian secara simultan (Uji F) bahwa Pola Komunikasi Orang Tua Tunggal $\left(\mathrm{X}_{1}\right)$ dan Kelompok Teman Sebaya $\left(\mathrm{X}_{2}\right)$ Memiliki pengaruh signifikan terhadap prestasi belajar siswa kelas XI Pemasaran SMK Negeri 7 Medan T.A 2019/2020. Dimana, $f_{\text {hitung }}$ sebesar 3,562, $f_{\text {tabel }}$ sebesar 3,32 dan nilai signifikan sebesar 0,041. Hal ini menunjukkan bahwa $f_{\text {hitung }}>\mathrm{f}_{\text {tabel }}$ yaitu $3,562>3,32$ dan nilai signifikan $\alpha(0,041<$ $0,05)$.

\section{REFERENSI}

Arlin. 2016. Pola Komunikasi Single Parent Dalam Mendidik Anak. JOM FISIP.
Vol.3/No.1/Februari/2016. Fakultas Ilmu Sosial Dan Politik Universitas Bina Widya.

Aw, Suranto. 2011. Komunikasi Interpersonal. Yogyakarta: Graha Ilmu

Aziz, dkk. 2015. Hubungan Antara Kelompok Teman Sebaya Dengan Prestasi Belajar Siswa SMKN 8 Bandung. Jurnal Pendidikan Teknik Mesin. Vol.2/No.2/Desember/2015.

Departemen Pendidikan Teknik Mesin Universitas Pendidikan Indonesia

Cangra, Hafied. 2016. Pengantar Ilmu Komunikasi. Jakarta: PT RajaGrafindo Persada.

Clarisa, Hedi. Pola Komunikasi Pengasuhan Ibu Single Parent. Jurnal Ilmu Komunikasi. Jurusan Ilmu Komunikasi Universitas Diponegoro Semarang

Devito. 2011. Komunikasi Antarpribadi. Tangerang Selatan: Kharisma Publishing Book.

Effendy. 2013. Ilmu Komunikasi Teori Dan Praktek. Bandung: PT Remaja Rosdakarya.

Fithri, Rizma. 2014. Psikologi Belajar. Surabaya: UIN Sunan Ampel. Gurning, Aswita. 2018. Metodologi Penelitian Pendidikan. Medan: KMedia

Hardjana, Agus. 2009. Komunikasi Intrapersonal \& Interpersonal. Yogyakarta: Kanisius.

Littlejohn. 2014. Teori Komunikasi. Jakarta: Salemba Humanika.

Martalena, dkk. Hubungan Kelompok Teman Sebaya (Peer Group) Dengan Prestasi Belajar Siswa Kelas XII IPS Di SMAN 1 Padang Ganting Kecamatan padang Ganting Kabupaten Tanah Datara. Fakultas Ilmu Sosial Dan Politik STKIP PGRI Sumatera Barat.

Mulyana, Deddy. 2010. Ilmu Komunikasi Suatu pengantar. Bandung: PT Remaja Rosdakarya.

Putri. 2016. Pola Komunikasi Dan Hubungan Interpersonal Ibu Single Parent Dan 
Anaknya (Studi Kasus Pada Siswa SMP Negeri 7 Kotabumi). Lampung: Skripsi Universitas Lampung

Sari. 2018. Pengaruh Kelompok Teman Sebaya Dan Minat Belajar Terhadap Prestasi Belajar Pada Mata Pelajaran Ekonomi Kelas XI IPS SMA Swasta Katolik Tri Sakti Medan T.A 2018/2019. Medan: Skripsi Universitas HKBP Nomensen

Siti. 2016. Pola Komunikasi Pengasuhan Single Parent Terhadap Anak. Makassar: UIN Alauddin

Slameto. 2010. Belajar Dan Faktor-Faktor Yang Mempengaruhinya. Jakarta: Rineka Cipta.

Syam, Nina. 2012. Psikologi Sosial Sebagai Dasar-Dasar Ilmu Komunikasi. Bandung: Simbiosa Rekatam Media.

West. 2013. Pengantar Teori Komunikasi Analisis Dan Aplikasi. Jakarta: Salemba Humanika.

Wulandari, Oksyta. 2016. Pemeliharaan Hubungan Antara Orang Tua Yang Bercerai Dan Anak (Studi Kualitatif Deskriptif Komunikasi Antarpribadi Antara Orang Tua Yang Memiliki Hak Asuh Dengan Anaknya). Surakarta: Universitas Muhammadiyah Surakarta. 